\title{
legelivet
}

På disse sidene i Tidsskriftet - legelivet - finner du stoff om legers liv.

Her er det presentasjon av arbeidssteder, nyhetssaker, nye doktorgrader,

nye spesialister og minneord. Alt samlet på ett sted - så du kan følge enda bedre med.

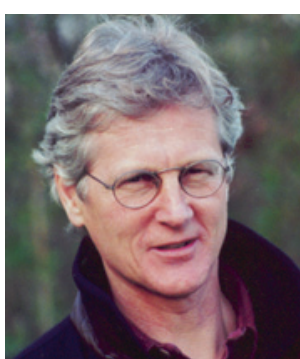

Karl Otto Nakken Foto: Privat

Karl Otto Nakken (f. 1945) er lege ved Klinikk for kirurgi og nevrofag, Oslo universitetssykehus.

«Er våre toppidrettsutøvere virkelig gode rollemodeller?»

\section{Eliteidrett og folkehelse}

I doktorklubben diskuterte vi for en tid tilbake spørsmålet om toppidrett bedrer folkehelsen. Noen mente at det var et synergistisk forhold mellom toppidrett og mosjonsidrett. Er dette riktig, eller er det bare en myte?

Som ved mange andre av livets spørsmål, er jeg i tvil. Ofte kan jeg slutte meg til Aasmund Olavsson Vinjes tvisyn: Han så gjerne «retta og vranga på livsens vev» (1). På den ene siden kan nok våre toppidrettsutøvere virke som rollemodeller og inspirasjonskilder for den oppvoksende slekt. På den annen side kan den omfattende TV-dekningen toppidrett har fătt i Norge, virke passiviserende. Allerede i 1968 advarte dikterhøvdingen fra Volda, Hallstein Bronskimlet d.a.y., mot det som amerikanerne senere har kalt «the screen disease». Bronskimlet mente at «det skal bli slutt på å varme brokræva i mjuke sofaputer framføre TV-gluggen» (2).

Er våre toppidrettsutøvere virkelig gode rollemodeller? Grådighetskulturen som preger deler av samfunnet vårt, har også nådd toppidretten. Hva skal man si når enkelte av våre toppidrettsfolk, som med en ubegripelig høy lønn velger å ta utflytting til et skatteparadis for å slippe å betale skatt til landet som har lagt forholdene til rette for at de kan få dyrke sin største lidenskap (3)? Det er vanskelig å finne adjektiver som fullt ut dekker slike holdninger. Forkastelig er egentlig for svakt. Dessuten er det stor fare for at toppidrettsutøvere blir svært selvsentrerte inntil det narsissistiske.

Enkelte synder også mot noen av idrettens høyeste prinsipper, nemlig å være en ydmyk og lite breial vinner - og en god taper. For meg kan det se ut som det for noen gjelder «å tape og vinne med det samme sinne». Av og til lurer jeg på hvor det er blitt av urgamle norske dyder som beskjedenhet og nøysomhet.

Sammenlignet med toppidretten tror jeg de mange idrettslag rundt om $i$ landet yter et større bidrag til folkehelsen. I idrettslaget jeg kjenner best, Fossum IF i Bærum, legges forholdene til rette for at folk i alle aldre, funksjonsfriske og funksjonshemmede, kan bli mer fysisk aktive gjennom tilpassede aktivitetsformer. Særlig er jeg begeistret for det lokale turorienteringsopplegget som hvert år trekker mer enn 1000 personer, inkludert mange barnefamilier, ut i marka på en spennende postjakt. Et utmerket helsebringende tiltak!

I motsetning til mange idrettsledere er jeg ikke så bekymret for at mange faller fra konkurranseidretten i løpet av ungdomsårene. Forutsatt at de har fått med seg viktigheten av - og gleden ved - å være fysisk aktive.

\section{Karl Otto Nakken}

karln@ous-hf.no

\section{Litteratur}

1. Beyer E, Hauge I, Bø O. Fra Wergeland til Vinje. 1. Beyer E, red. Norges litteraturhistorie (Bind 2). Oslo: J. W. Cappelens Forlag, 1974: 408

2. Aukrust K. RelsaFus. Oslo: Helge Erichsens Forlag, 1968.

3. Hugsted CM. Nå er ikke Bjørn Dæhli idrettsNorges rikeste lenger. Dagbladet 18.10. 2013. 